九州大学学術情報リポジトリ

Kyushu University Institutional Repository

Comparative Analyses of Japanese Wood Mice from the Oki Islands and the Mainland of Japan Based on Biochemical Genetics and Cytogenetics

Hirai, Hirohisa

Zoological Laboratory, Faculty of Agriculture, Kyushu University

Moriwaki, Kazuo

Department of Cytogenetics, National Institute of Genetics

Uchida, Teruaki

Zoological Laboratory, Faculty of Agriculture, Kyushu University

https://doi.org/10.5109/23714

出版情報: 九州大学大学院農学研究院紀要. 25 (1)，pp.1-8，1980-08. Kyushu University バージョン：

権利関係 : 


\title{
Comparative Analyses of Japanese Wood Mice from the Oki Islands and the Mainland of Japan Based on Biochemical Genetics and Cytogenetics
}

\author{
Hirohisa Hirai ${ }^{1}$, Kazuo Moriwaki ${ }^{2)}$ and Teru Aki Uchida \\ Zoological Laboratory, Faculty of Agriculture, \\ Kyushu University 46-06, Fukuoka 812 \\ (Received January 7, 1980)
}

\begin{abstract}
Japanese wood mice from the Oki Islands (Dozen and Dogo) and the mainland of Japan were investigated at 15 loci of biochemical characters using electrophoresis by thin layer acrylamide gel and by cellulose acetate membrane. The genetic distance computed from those gene frequency data suggested that difference between Apodemus speciosus speciosus from the mainland and A. navigator navigator from the Oki Is. was at the subspecies level. Chromosome C-band patterns were also compared, but no significant difference was observed between the island and mainland forms. The proposition of Hiraiwa et al. (1958), who stated that the populations of Dozen and Dogo within the Oki Is. might be distinguished at subspecies level by morphological features, would be denied by the genetic distance estimated in this study. They belong probably to different local races.
\end{abstract}

\section{INTRODUCTION}

The Oki Islands are located about $60 \mathrm{~km}$ far from the Shimane Peninsula, consisting of Dozen and Dogo. Thomas (1905) classified Japanese wood mice from the mainland of Japan into Micromys speciosus speciosus and those from Dogo of the Oki Is., M. s. navigator. Thereafter, Aoki (1915), Tokuda (1941) and Imaizumi $(1962,1964)$ termed the mice from the mainland as Apodemusspeciosus speciosus and those from the Oki Is. as A. s. navigator by their morphological features. Moreover, Hiraiwa et al. (1958) and Miyao et al. (1968) described that the tail ratio of navigator was lower than that of speciosus. Further they reported that the dead center represented by the distance between the first upper molars $\left(m_{1}-m_{1}\right)$ of skull was significantly longer in specimens from the Oki Is., especially from Dozen, than in that of the mainland comparing these 2 populations by dividing into 5 age-matched groups. Due to these differences, they claimed that the animals from Dozen could be distinguished from navigator of Dogo at the level of subspecies. On the other hand, Imaizumi (1971) considered the animal from the Oki Is. as a separate species, A. navigator navigator, which was distinct from A. s. speciosus of the mainland while con-

1) Present address: Department of Parasitic Diseases, Kumamoto University School of Medicine, Kumamoto 860

2) Department of Cytogenetics, National Institute of Genetics, Mishima 411 
sidering individual variation. However, the above-mentioned classifications have not yet been completely accepted.

We examined these two queries of subspeciation between Dozen and Dogo mice and speciation between the Oki Is. and the mainland mice by estimating the genetic distance between them and comparing their chromosome C-band patterns.

\section{MATERIALS AND METHODS}

Specimens of 53 individuals of Japanese wood mice were collected from the following 5 localities: Dozen and Dogo of the Oki Is., and Daisen, Tottori and Toyama of the mainland, using live-traps (Fig. 1).

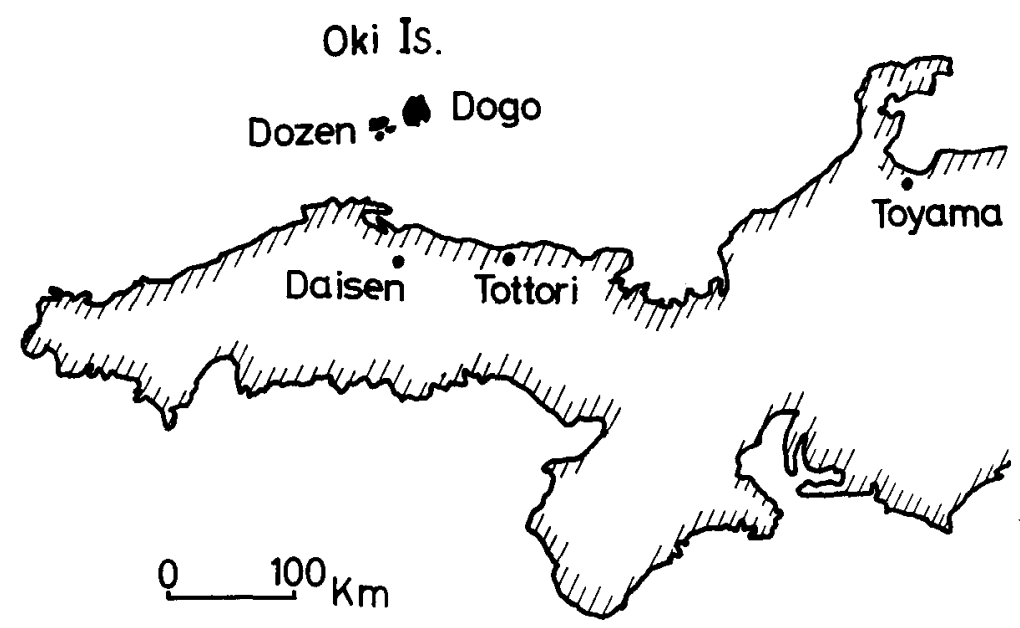

Fig. 1. Collection localities of Japanese wood mice used as materials.

The proteins of blood plasma, hemolysate and liver extract were analyzed electrophoretically by thin layer acrylamide gel and cellulose acetate membrane (Separax, Fuji Film Co. Ltd.). Approximately $1 \mathrm{ml}$ of blood was obtained by suborbital puncture with a heparinized pasteur pipette. Whole blood was centrifuged at $3,500 \mathrm{rpm}$ for $20 \mathrm{~min}$ at $4^{\circ} \mathrm{C}$. After decanting plasma, the remaining cell fraction was washed twice with $0.85 \%$ saline. To the cells were then added double volumes of distilled water and an equal volume of toluene for hemolysis. After stirring, the suspension was left for $10 \mathrm{~min}$ at $4^{\circ} \mathrm{C}$, and was centrifuged at $26,000 \times \mathrm{g}$ for $30 \mathrm{~min}$ at $4^{\circ} \mathrm{C}$. The lower watersoluble fraction was removed for later use. Liver was homogenized in an equal volume of distilled water and centrifuged at $26,000 \mathrm{xg}$ for $30 \mathrm{~min}$ at $4^{\circ} \mathrm{C}$. The supernatant was examined as the liver extract. The above-mentioned three samples, plasma, hemolysate and liver extract, were stored at $-20^{\circ} \mathrm{C}$ until electrophoresis.

The proteins scored were as follows: esterase (Es), malic enzyme (Mod- 
1), isocitrate dehydrogenase (Id-1), phosphoglucomutase (Pgm-1), glucose phosphate isomerase (Gpi), hemoglobin $(\mathrm{Hb})$, pre-albumin (Pre-Alb), albumin (Alb), $\alpha_{2}$ protein $\left(\alpha_{2} \mathrm{P}\right)$, transferrin (Tf) and $\alpha_{2}$ macroglobulin $\left(\alpha_{2} \mathrm{MG}\right)$. Five Es loci (Es-lo, Es-3, Es-1, Es-4 and Es-2) were numbered by checking the loci in inbred mice. Es, Pre-Alb, Alb, $\alpha_{2} \mathrm{P}$, Tf and $\alpha_{2} \mathrm{MG}$ were run using acrylamide gel with plasma, and $\mathrm{Hb}$ and Gpi using Separax with hemolysate, and Mod-l, Id-l and Pgm-1 using Separax with liver extract.

Thin layer acrylamide gel electrophoresis was carried out according to the method of Hirai et al. (1978). Cellulose acetate membrane electrophoresis was run for about $50 \mathrm{~min}$ at $0.4 \mathrm{~mA} / \mathrm{cm}$ constant current using Verona1 buffer ( $\mu .06, \mathrm{pH} 8.6)$ at room temperature (Ogawa, 1965).

Coomasie brilliant blue was used for staining the plasma proteins on the acrylamide gel, and Ponceau 3R for hemoglobin on the Separax. Staining methods for the following enzyme proteins were followed the procedures of various workers (in parenthesis) : Es (Popp and Popp, 1962), Mod-l (Shows and Ruddle, 1968), Id-l (Henderson, 1965), Pgm-1 (Shows et al., 1969) and Gpi (DeLorenzo and Ruddle, 1969).

Genetic distances of mice from 5 localities were calculated by the formula of Nei (1972) using 15 loci.

Cultures of tail tissues were grown in Eagle's MEM supplemented with 20 $\%$ calf serum in order to examine chromosomes. Cultures were harvested by trypsinization after Colcemid treatment $(0.05 \mu \mathrm{g} / \mathrm{ml})$ for $20 \mathrm{~min}$. Cells were treated with $1 \%$ sodium citrate for 15 min, fixed in methanol-acetic acid (3: 1 ) and air-dried on clean slides. G- and C-banding preparations were performed with the procedure described by Seabright (1971) and Sumner (1972), respectively. The chromosome number was determined according to the method by Tsuchiya (1974).

\section{RESULTS}

Allele frequencies are shown in Tables 1 and 2. Alleles were numbered according to their electrophoretic mobilities. Esterase (Es-lo, Es-3, Es-1, Es-4 and Es- ), Pre-Alb and $\alpha_{2} \mathrm{P}$ loci showed polymorphism in each population, but the variation on Tf was shown only in one mouse from Daisen. No polymorphism was detected in Mod-l, Id-l, Pgm-1, Gpi, Hb, Alb and $\alpha_{2} \mathrm{MG}$ in the mice from all localities.

Genetic distance (D) is shown in Table 3. The $\mathrm{D}$ value between the mice from Dozen and Dogo within the Oki Is. was 0.026, 0.033 between Daisen and Tottori, 0.050 between Daisen and Toyama and 0.026 between Tottori and Toyama. Thus, the calculated mean value of $\mathrm{D}$ within the mainland was at $0.036 \pm 0.012$, that between the Oki Is. and the mainland was at $0.064 \pm 0.020$.

Chromosomes provided with positive C-band were A-1, A-2, A-6, A-13, SM-1, SM-2, SM-3, ST-1, M-1 and X. Distribution of the C-band obtained in these chromosomes is shown in Table 4; the C-band of A-2 chromosome was stained at middle point of long-arm and that of ST-1 throughout the whole long-arm. The C-band of $\mathrm{X}$ chromosome was very deeply stained. There 
Table 1. Allele frequencies at five esterase loci in Japanese wood mice collected from five localities.

\begin{tabular}{rrrrrr}
\hline Locality & Dozen & Dogo & Daisen & Tottori & Toyama \\
\hline Es-10 & & & & & \\
$\mathbf{a}$ & $\mathbf{0 . 1 1 1}$ & 0.167 & 0.045 & 0.000 & 0.143 \\
$\mathbf{b}$ & $\mathbf{0 . 8 8 9}$ & 0.833 & 0.955 & 1.000 & 0.857 \\
Es- 3 & & & & & \\
$\mathbf{a}$ & 0.611 & 0.625 & 0.409 & 0.643 & 1.000 \\
$\mathbf{b}$ & 0.389 & 0.375 & 0.591 & 0.357 & 0.000 \\
Es- 1 & & & & & \\
$\mathbf{a}$ & $\mathbf{0 . 4 4 5}$ & 0.417 & 1.000 & 0.929 & 0.857 \\
$\mathbf{b}$ & $\mathbf{0 . 5 5 5}$ & 0.583 & 0.000 & 0.071 & 0.143 \\
Es- & & & & & \\
$\mathbf{a}$ & 1.000 & 0.750 & 0.500 & 0.179 & 0.500 \\
$\mathbf{b}$ & $\mathbf{0 . 0 0 0}$ & 0.250 & 0.500 & 0.821 & 0.500 \\
Es- & & & & & \\
$\mathbf{a}$ & 0.111 & 0.667 & 0.136 & 0.643 & 0.429 \\
$\mathbf{b}$ & 0.000 & 0.000 & 0.000 & 0.000 & 0.000 \\
$\mathbf{c}$ & 0.000 & 0.042 & 0.273 & 0.036 & 0.000 \\
$\mathbf{d}$ & $\mathbf{0 . 3 3 3}$ & 0.125 & 0.318 & 0.143 & 0.146 \\
e & $\mathbf{0 . 1 1 1}$ & 0.042 & 0.000 & 0.107 & 0.143 \\
$\mathbf{f}$ & $\mathbf{0 . 4 4 4}$ & 0.125 & 0.273 & 0.071 & 0.143 \\
\hline
\end{tabular}

Table 2. Allele frequencies at three nonenzymatic loci in Japanese wood mice collected from five localities.

\begin{tabular}{|c|c|c|c|c|c|}
\hline Locality & Dozen & Dogo & Daisen & Tottori & Toyama \\
\hline $\begin{array}{r}\text { Pre-Alà } \\
\text { b }\end{array}$ & 0.770 .222 & 0.6670 .333 & 0.9550 .0 .15 & 0.9640 .036 & 0.7860 .214 \\
\hline$\alpha_{2} \mathrm{P}$ & $\begin{array}{l}0.667 \\
0.333\end{array}$ & $\begin{array}{l}0.542 \\
0.458\end{array}$ & $\begin{array}{l}0.833 \\
0.167\end{array}$ & $\begin{array}{l}0.607 \\
0.393\end{array}$ & $\begin{array}{l}0.500 \\
0.500\end{array}$ \\
\hline $\mathrm{Tf}$ & $\begin{array}{l}1.000 \\
0.000\end{array}$ & $\begin{array}{l}1.000 \\
0.000\end{array}$ & $\begin{array}{l}0.955 \\
0.045\end{array}$ & $\begin{array}{l}1.000 \\
0.000\end{array}$ & $\begin{array}{l}1.000 \\
0.000\end{array}$ \\
\hline
\end{tabular}

Table 3. Coefficient of genetic distance (D) between Japanese wood mice from five localities.

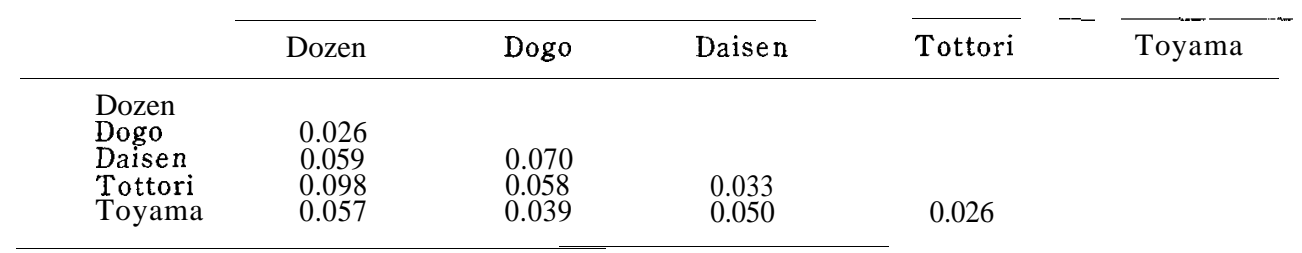

seemed to be characteristic geographical variations in ST-1 chromosomes. Namely, all the individuals from Dozen, Dogo and Daisen showed homozygosis of positive band $(+/+)$, but animals from Tottori showed polymorphism consisting of positive $(+/+)$ and negative $(-/-)$ homozygosis and heterozygosis 


\section{Comparative Analyses of Japanese Wood Mice}

Table 4. Distribution of positive C-band in Japanese wood mice collected from five localities.

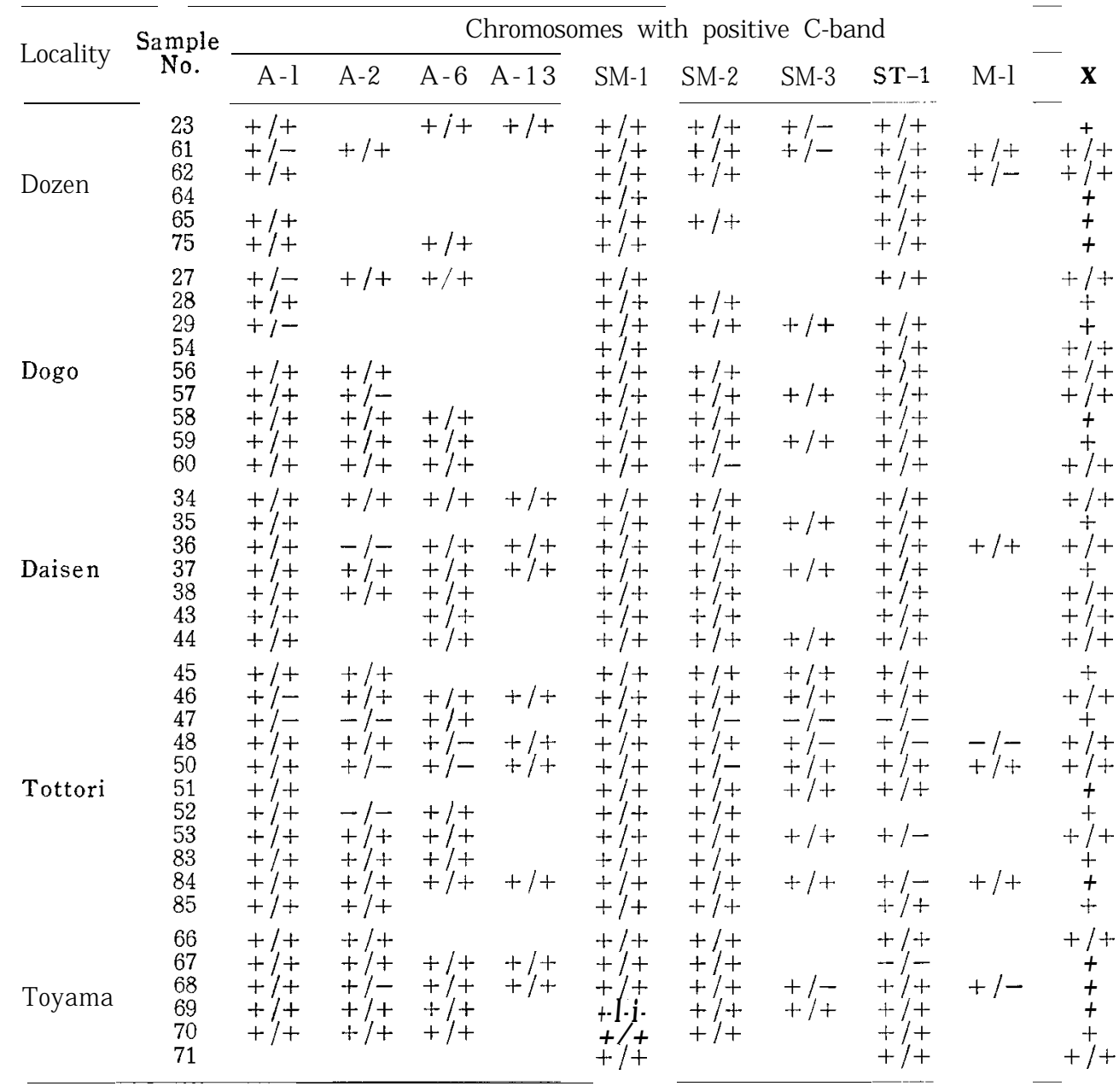

$(+/-)$, those from Toyama having polymorphism devoid of the last.

\section{DISCUSSION}

Nei (1972) proposed a formula to draw genetic distance due to the idea that if two populations are isolated from each other for geographic or reproductive reasons, they would tend to accumulate different genes individually. $\mathrm{He}$ calculated the value of genetic distance applying this formula to the data of gene frequencies in various animals reported by other authors. From the results obtained, he claimed that in most cases of local races the genetic distance was less than $\mathbf{0 . 0 2}$, while the value between different species was generally more than that between different subspecies. The intergeneric D val. 
ue of all the cases was more than 1.00. Since then, this formula has been widely used as a reliable method to estimate genetic distance between two populations.

In order to show criteria of local races in rodents, $\mathrm{Nei}$ (1975) used the gene frequency obtained in mice by Selander et al. (1969). They calculated the D value at $0.010-0.024$ on 41 loci in 69 individuals of Mus musculus musculus obtained from 4 localities in the Jutland Peninsula. Recently, Britton and Thaler (1978) obtained the D value of 0.025 between local races of Mus musculus brevirostris from the St. Clement and the Villeroy regions. We obtained a value of 0.026 as the $D$ value between Dozen and Dogo mice. Comparing this value with the above ones, we assumed that Japanese wood mice of both islands belonged to different local races.

Moreover, $\mathrm{Nei}$ (1975) calculated the $\mathrm{D}$ value at 0.194 between M.m.domesticus and $M$. m. musculus on the basis of the data by Selander et al. (1969). This value may be a criterion useful in comparing two subspecies of rodents. Britton and Thaler (1978) concluded that M. spretas and M. musculus were apparently of distinct species basing on the $D$ values from 0.423 to 0.606 . The mean value of $\mathrm{D}$ between A. n.navigator and A. s. speciosus was $0.064 \pm 0.02$ as previously stated in our study. Comparing this value with the above ones, we cannot agree with Imaizumi's conclusion that A. n. navigator and A. s. speciosus are distinct species, granting that it is possible to distinguish between them at subspecies level.

We compared the centromeric heterochromatin of chromosomes between Dozen and Dogo mice, and the result revealed no differences. This finding suggests that little divergence has occurred between these populations. In addition, we failed to detect any distinguishable differences in C-banding pattern between the Oki Is. mice and the mainland ones. Deaven et al. (1977) reported that there were marked differences in C-banding pattern among three species belonging to genus Peromyscus ( $P$. eremicus, $P$. maniculatus and $P$. crinitus). Yosida (1975) detected differences in C-banding pattern between Rattus rattus and $R$. norvegicus. It seems that these findings and those of ours do not support a suggestion of Imaizumi who distinguished Japanese wood mice of the Oki Is. from those of the mainland as a different species.

We can not argue in detail geographical variation in C-band of ST-I, but this feature seems to be spreading in regions between Tottori and Toyama. In the future, if an improvement of the technique in staining $\mathrm{C}$-band is achieved, and if much more individuals from many localities in Japan are surveyed, we may obtain more accurate data with regard to the geographical variations of chromosomes.

However, in animals used here also, it could not be denied that the individuals of Dozen are markedly larger in their external morphology than those of Dogo and the mainland. It seems reasonable to postulate that morphological evolution might not be parallel to the absolute time elapsed. This may become an example that the molecular evolution rate in "phylogenetic relic" is not less genetically variable than some other animals belonging to horotelic lines (Selander et al., 1970; Stenzel, 1974). This report may also be re- 
garded as an example of the above in a broad sense. Although morphological features have been varied to some extent under the environments of isolated islands, genetic variations were of undetectable degree by biochemical and cy. togenetic techniques used here.

\section{ACKNOWLEDGEMENTS}

We wish to express our thanks to Dr. K. Tsuchiya, Hokkaido Institute of Public Health and Mr. M. Minezawa, Primate Research Institute, Kyoto University, and Professor I. Tada, Department of Parasitic Diseases, Kumamoto University School of Medicine for their valuable advice. We are grateful to Messrs. T. Shiroishi, H. Akaza, F. Yamada, M. Akanuma, Y. A be, S. Tsuda and A. Imazu, who helped us in collecting samples. Thanks are also due to the staff of Department of Cytogenetics, National Institute of Genetics, and the staff and graduate students of Zoological Laboratory, Kyushu University for their encouragement, and to Professor E. W. Jameson, Jr. of the University of California for comments on the manuscript.

\section{REFERENCES}

Aoki, B. 1915 Nipponsan Nezumika, Zool.Soc,, Tokyo, pp. 31-40 (in Japanese)

Britton. J. and L. Thaler 1978 Evidence for the presence of two sympatric species of mice (genus Mus L.) in southern France based on biochemical genetics. Biochem. Genet., 16: 213-225

Deaven, L. L., L. Vidal-Rioja, J. H. Jett and T. C. Hsu 1977 Chromosomes of P eromyscus (Rodentia. Cricetidae). VI. The genomic size. Cytogenet. Cell Genet., 19: 241-249

DeLorenzo, K. J. and F. H. Ruddle 1969 Genetic control of two electrophoretic variation of glucophosphate isomerase in the mouse (Musmusculus). Biochem. Genet., 3: 151-162

Henderson, N. S. 1965 Isozymes of isocitrate dehydrogenase: Subunit structure and intracellular location. J. Exp. Zool., 158: 263-274

Hirai, H., K. Moriwaki and T. A. Uchida 1978 Comparative analyses of Japanese wood mice between Oki Islands and Mainland from the view points of biochemistry and cytogenetics. Ann. Rep. Nat. Inst. Genetics, Japan, 28: 36-37

Hiraiwa, Y. K., M. Tokuda, T. A. Uchida and H. Sugiyama 1958 Some small mammals from the Islands of Oki, with especial reference to detail examination of their subspecific characteristics. Sci. Bull. Fac. Agr., Kyushu Univ., 16: 547-574 (in Japanese with English summary)

Imaizumi, Y. 1962 On the species formation of the Apodemus speciosus group, with special reference to the importance of relative values in classification. Part 1. Bull. Nat. Sci. Mus. Tokyo, 5: 163-259

Imaizumi, Y. 1964 On the species formation of the Apodemus speciosus group, with special reference to the importance of relative values in classification. Part 2. Bull. Nat. Sci. Mus. Tokyo, $7: 127-177$

Imaizumi, Y. 1971 Japanese wood mice. Animal-life, 1: 79-81 (in Japanese)

Miyao, T., T. Möri and T. Morozumi 1968 Studies on Apodemus speciosus from the Island of Oki. Mamm. Sci., (16): 37-51 (in Japanese with English summary)

Nei. M. 1972 Genetic distance between populations. Amer. Natur., 106: 283-292

Nei, M. 1975 Differentiation of populations and speciation. In "Molecular Population Genetics and Evolution," North-Holland/American Elsevier, pp. 175-209 
Ogawa, N.1965 Method of cellulose acetate membrane electrophoresis. In "Method of Electrophoretic Experiment," ed. by The Society of Electrophoresis. Bunkodo, pp. 111156 (in Japanese)

Popp, R. A. and D. M. Popp 1962 Inheritance of serum Esterase having different electrophoretic patterns among inbred strains of mice. J.Hered., 53: 111-114

Seabright, M. 1971 A rapid banding technique for human chromosomes. Lancet, (7731): 971-972

Selander, R. K., W. G. Hunt and S. H. Yang 1969 Protein polymorphism and genicheterozygosity in two European subspecies of the house mouse. Evolution, 23: 379-390

Selander, R. K., S. Y. Yang, R. C. Lewontin and W. E. Johnson 1970 Genetic variation in the horseshoe crab (Limulus, Polyphemus), a phylogenetic "relic". Evolution, 24: 402-414

Shows, T. B. and F. H. Ruddle 1968 Malate dehydrogenase: Evidence for tetrameric structure in Musmusculus. Science, 160: 1356-1357

Shows, T. B., F. H. Ruddle and T. H. Roderick 1969 Phosphoglucomutase electrophoretic variations in the mouse. Biochem. Genet.. 3: 25-35

Stenzel, P. 1974 Opossum Hb chain sequence and neutral mutation theory. Nature. 252: 62-63

Sumner, A. T. 1972 A simple technique for demonstrating centromeric heterochromatin. Expt. Cell Res., 75 : 304-306

Thomas, 0. 1905 The Duke of Bedford's Zoological Exploration in Eastern Asia. 1. List of mammals obtained by Mr. M. P. Anderson in Japan. Proc. Zool. Soc. London, 1905, 2: 331-363

Tokuda, M. 1941 A revised monograph of the Japanese and Manchou-Korean Muridae. Biogeographica. 4 : 1-155

Tsuchiya, K. 1974 Cytological and biochemical studies of Apodemus speciosus group in Japan. J.Mamm.Soc. Japan, 6: 67-87 (in Japanese with English abstract)

Yosida. T. H. 1975 Diminution of heterochromatic C-bands in relation to the differentiation of Rattus species. Proc. Japan Acad., 51: 659-663 